OPEN ACCESS

Edited by:

Tatsuo Shioda,

Osaka University, Japan

Reviewed by:

Alex Compton,

National Cancer Institute at Frederick,

United States

Noah Sather.

University of Washington,

United States

*Correspondence:

Qutayba Hamid

qalheialy@sharjah.ac.ae

Specialty section

This article was submitted to

Viral Immunology,

a section of the journal

Frontiers in Immunology

Received: 16 April 2020

Accepted: 28 May 2020

Published: 10 June 2020

Citation:

Hachim MY, Al Heialy S, Hachim IY,

Halwani $R$, Senok AC, Maghazachi AA

and Hamid Q (2020)

Interferon-Induced Transmembrane

Protein (IFITM3) Is Upregulated

Explicitly in SARS-CoV-2 Infected

Lung Epithelial Cells.

Front. Immunol. 11:1372.

doi: 10.3389/fimmu.2020.01372

\section{Interferon-Induced Transmembrane Protein (IFITM3) Is Upregulated Explicitly in SARS-CoV-2 Infected Lung Epithelial Cells}

\author{
Mahmood Yaseen Hachim ${ }^{1,2}$, Saba Al Heialy ${ }^{2,3}$, Ibrahim Yaseen Hachim ${ }^{1}$, Rabih Halwani ${ }^{1}$, \\ Abiola C. Senok ${ }^{2}$, Azzam A. Maghazachi ${ }^{1}$ and Qutayba Hamid ${ }^{1,3 *}$ \\ ${ }^{1}$ Sharjah Institute for Medical Research, College of Medicine, University of Sharjah, Sharjah, United Arab Emirates, ${ }^{2}$ College \\ of Medicine, Mohammed Bin Rashid University of Medicine and Health Sciences, Dubai, United Arab Emirates, \\ ${ }^{3}$ Meakins-Christie Laboratories, Research Institute of the McGill University Health Center, Montreal, QC, Canada
}

Current guidelines for COVID-19 management recommend the utilization of various repurposed drugs. Despite ongoing research toward the development of a vaccine against SARS-CoV-2, such a vaccine will not be available in time to contribute to the containment of the ongoing pandemic. Therefore, there is an urgent need to develop a framework for the rapid identification of novel targets for diagnostic and therapeutic interventions. We analyzed publicly available transcriptomic datasets of SARS-CoV infected humans and mammals to identify consistent differentially expressed genes then validated in SARS-CoV-2 infected epithelial cells transcriptomic datasets. Comprehensive toxicogenomic analysis of the identified genes to identify possible interactions with clinically proven drugs was carried out. We identified IFITM3 as an early upregulated gene, and valproic acid was found to enhance its mRNA expression as well as induce its antiviral action. These findings indicate that analysis of publicly available transcriptomic and toxicogenomic data represents a rapid approach for the identification of novel targets and molecules that can modify the action of such targets during the early phases of emerging infections like COVID-19.

Keywords: COVID-19, SARS-CoV-2, interferon-induced transmembrane proteins, valproic acid, antiviral immunity

\section{INTRODUCTION}

Coronaviruses are a large family of viruses that were first described over 50 years ago (1). Since the turn of the millennium, there have been two major global outbreaks caused by coronaviruses, namely SARS-CoV in 2003 and MERS-CoV in 2012 (2). The ongoing COVID-19 pandemic caused by SARS-CoV-2 represents the third and most devastating of these outbreaks. These outbreaks, notably the COVID-19 pandemic, are harsh reminders of the challenges posed by emerging infectious diseases. The global impact of the COVID-19 pandemic has brought to the forefront the need to rapidly develop and deploy an effective vaccine. However, despite ongoing concerted research efforts, it is accepted that such a vaccine will not be available in time to contribute to the containment of the ongoing pandemic. Current management guidelines include the use of repurposed drugs such as chloroquine and its analog hydroxychloroquine as well as antiviral agents (3). However, the need for well-designed clinical trials to validate their efficacy continues to be highlighted. To effectively address the ongoing COVID-19 pandemic, there is a recognized need for 
a framework for rapid identification of novel targets for diagnostic and therapeutic interventions as well as determine clinically approved drugs with high potential for repurposed use against SARS-CoV-2. Publicly available transcriptomic datasets generated from SARS-CoV infected humans, and mammalian cells represent a wealth of data that could be used to identify consistent differentially expressed genes, which could then be validated against SARS-CoV-2 infected epithelial cells transcriptomic datasets. A comprehensive toxicogenomic analysis of the identified genes could potentially identify possible interactions with clinically proven drugs. This simple approach can be used for the rapid identification of novel targets and drugs for further validation. In this study, we have applied this approach, and our findings have identified IFITM3 as an early upregulated gene and indicate that valproic acid enhances IFITM3 mRNA expression and antiviral action.

\section{MATERIALS AND METHODS}

Publicly available transcriptomic datasets were retrieved from Gene Expression Omnibus (GEO) (https://www.ncbi.nlm.nih.gov/geo/). Only microarray gene expression datasets with the word "SARS-COV," virus, or modified strain infected vs. mock-infected and no more than $48 \mathrm{~h}$ after the infection. Twelve datasets fulfilled the criteria, as detailed in Table 1. We used GEOquery and limma R packages through the GEO2R tool for each dataset (12). After sorting the genes according to the False Discovery Rate (FDR), the top 2,000 differentially expressed probes with FDR $<0.05$ were selected from each dataset. The annotated genes of the 5,000 probes in each dataset were intersected with differentially expressed genes (DEGs) from all other datasets. The DEGs that were common in at least 9 out of the $12(75 \%)$ datasets were identified as shared genes that are consistently DEG in the first $48 \mathrm{~h}$ of SARS-COV infection. Enriched Ontology Clustering for the identified genes was performed to explore using the Metascape (http://metascape.org/gp/index.html\#/main/step1). The shortlisted genes expression was then explored in another dataset (GSE147507), where RNA-Sequencing of primary human lung epithelium (NHBE) mock-treated or infected with SARS-CoV-2 was done to examine whether there is a difference in the response of SARS-CoV-2 from other strains in terms of DEGs (13).

TABLE 1 | List of publicly available transcriptomics datasets retrieved from Gene Expression Omnibus (GEO) and used in the study.

\begin{tabular}{|c|c|c|c|c|c|}
\hline No. & Study title & Model & Strain & Gene set ID & References \\
\hline 1. & $\begin{array}{l}\text { Absence of host innate immune responses in SARS-CoV-infected } \\
\text { ferrets upon subsequent challenge }\end{array}$ & Ferret & SARS-CoV (TOR2) & GSE11704 & (4) \\
\hline 2. & $\begin{array}{l}\text { Dynamic innate immune responses of human bronchial epithelial cells } \\
\text { against SARS-CoV and DOHV infection }\end{array}$ & $\begin{array}{l}\text { 2B4 cells, a clonal } \\
\text { derivative of } \\
\text { Calu-3 cells }\end{array}$ & Urbani strain of SARS-CoV & GSE17400 & (5) \\
\hline 3. & $\begin{array}{l}\text { Comparative pathogenesis of three human and zoonotic SARS-CoV } \\
\text { strains in cynomolgus macaques }\end{array}$ & $\begin{array}{l}\text { Cynomolgus } \\
\text { macaques }\end{array}$ & $\begin{array}{l}\text { Recombinant SARS-CoV } \\
\text { bearing variant S } \\
\text { glycoproteins (Urbani, GZO2 } \\
\text { and HC/SZ/6103) }\end{array}$ & GSE23955 & (6) \\
\hline 4. & $\begin{array}{l}\text { SM001: SARS CoV MA15 infection of C57BI/ } 6 \text { mouse model - data } \\
\text { from } 4 \text { viral doses at 1, 2, } 4 \text { and } 7 \text { days post infection. }\end{array}$ & C57BL/6 mice & SARS CoV MA15 & GSE33266 & $(7)$ \\
\hline 5. & $\begin{array}{l}\text { SCL005: icSARS CoV Urbani or icSARS deltaORF6 infections of the } \\
\text { 2B4 clonal derivative of Calu-3 cells - Time course }\end{array}$ & Calu-3 cells & $\begin{array}{l}\text { icSARS CoV or the icSARS } \\
\text { deltaORF6 mutant }\end{array}$ & GSE33267 & (8) \\
\hline 6. & $\begin{array}{l}\text { SCL006,icSARS CoV urbani or icSARS Bat SRBD (spike receptor } \\
\text { binding domain from the wild type strain urbani to allow for infection of } \\
\text { human and non-human primate cells) infections of the 2B4 clonal } \\
\text { derivative of calu-3 cells - Time course }\end{array}$ & Calu-3 cells & $\begin{array}{l}\text { icSARS CoV or the cSARS } \\
\text { Bat SRBD strain }\end{array}$ & GSE37827 & (8) \\
\hline 7. & $\begin{array}{l}\text { SHAE002: SARS-CoV, SARS-dORF6 and SARS-BatSRBD infection of } \\
\text { HAE cultures. }\end{array}$ & HAE cultures & $\begin{array}{l}\text { SARS-CoV, SARS-dORF6 } \\
\text { or SARS-BatSRBD }\end{array}$ & GSE47960 & (9) \\
\hline 8. & $\begin{array}{l}\text { SCL008: icSARS CoV, icSARS-deltaNSP16 or icSARS ExoNI infections } \\
\text { of the 2B4 clonal derivative of Calu-3 cells - Time course }\end{array}$ & $\begin{array}{l}\text { 2B-4 cells (clonal } \\
\text { derivatives of } \\
\text { Calu-3 cells) }\end{array}$ & $\begin{array}{l}\text { icSARS CoV, icSARS } \\
\text { deltaNSP16 or icSARS } \\
\text { ExoNI }\end{array}$ & GSE48142 & (8) \\
\hline 9. & $\begin{array}{l}\text { SM003 - icSARS CoV, SARS MA15 wild type and SARS BatSRBD } \\
\text { mutant virus infections of C57BL6 mice - A time course }\end{array}$ & C57BL6 & $\begin{array}{l}\text { icSARS CoV, Wild Type } \\
\text { SARS MA15 or SARS } \\
\text { BatSRBD mutant viruses }\end{array}$ & GSE50000 & (8) \\
\hline 10. & $\begin{array}{l}\text { The PDZ-binding motif of SARS-CoV envelope protein is a determinant } \\
\text { of viral pathogenesis }\end{array}$ & $\begin{array}{l}\mathrm{BALB} / \mathrm{c} \text { Ola Hsd } \\
\text { mice }\end{array}$ & MA15 & GSE52920 & (10) \\
\hline 11. & $\begin{array}{l}\text { Genome wide identification of SARS-CoV susceptibility loci using the } \\
\text { collaborative cross }\end{array}$ & C57BL/6J & MA15 & GSE64660 & \\
\hline 12. & Mouse lung tissue transcriptome response to a mouse-adapted strain & C57BL6/NJ & MA15 & GSE68820 & $(11)$ \\
\hline
\end{tabular}




\section{RESULTS}

In total, 9,692 genes were differentially expressed genes (DEGs) between mock-infected and virally infected models in the 12 studies. Thirty-eight genes that were DEGs in at least 9 out of 12 studies (75\%) were considered common DEGs due to SARS$\mathrm{COV}$ infection of the lungs in the first $48 \mathrm{~h}$ post-infection. These genes are listed in Table 2.

\section{Species-Specific Response to SARS-CoV Infection}

In order to identify DEG in SARS-CoV infected lung tissuespecific to each of the models used and those which are shared, we intersected the DEGs from datasets that use the same model. Human epithelial cells datasets (GSE17400, GSE33267, GSE37827, GSE47960, and GSE48142), mice datasets (GSE33266, GSE50000, GSE52920, GSE64660, and GSE68820), Ferret (GSE11704) and Cynomolgus macaques (GSE23955) were all intersected with the COVID-19 infected epithelial cells dataset as shown in Figure 1. The number of DEG intersected between different species is listed in the Table 3. Epithelial cells infected with SARS-CoV-2 shared 9 DEGs (MX1, OAS3, XAF1, IFI44, MX2, IRF7, STAT1, IFIT3, and IFIT1) with Human Lung Cells, Mice, and Cynomolgus maca.

\section{The Identified Genes Are Involved in the Immune Response Against RNA Viruses}

As expected, the top genes identified are involved in innate immune responses against RNA viruses. These include the cytosolic DNA-sensing pathway, Toll-like receptor signaling pathway, and negative regulation of binding. Interferon (IFN) response to viral infections such as type I interferon signaling pathway, defense response to the virus, the antiviral mechanism by IFN-stimulated genes, regulation of type I interferon production, response to interferon-alpha, and regulation of defense response to virus and Influenza A, were also upregulated. Genes that play significant roles in activating immune systems such as regulation of response to cytokine stimulus, negative regulation of immune response, myeloid cell homeostasis, and positive regulation of the multi-organism process are also upregulated (Figure 2 and Table 4).

\section{IFITM3, OAS2, and MX1 Showed the Highest Upregulation in SARS-CoV-2 Infected Epithelial Cells}

The identified genes expression levels were higher in human bronchial epithelium infected with SARS-CoV-2 compared to those mock-infected (Figure 3). However, only IFITM3 showed a significant difference $(p<0.05)$, while two other genes OAS2 and MX1 showed a trend of enhancement, although it was not statistically significant ( $p=0.06$ using the two-stage linear stepup procedure of Benjamini, Krieger, and Yekutieli). IFITM3 mRNA levels were one of the highly expressed genes compared to the other identified genes at baseline in mock-infected HBE
TABLE 2 | Genes symbols and description for the common DEGs in 9 out of the 12 transcriptomics datasets due to SARS-CoV infection of the lung in the first $48 \mathrm{~h}$ post-infection.

\begin{tabular}{|c|c|c|}
\hline $\begin{array}{l}\text { Genes } \\
\text { symbol }\end{array}$ & Description & $\begin{array}{c}\text { Number of studies } \\
\text { where DEG was } \\
\text { identified }\end{array}$ \\
\hline DDX58 & DExD/H-box helicase 58 & 11 \\
\hline IFI44 & interferon induced protein 44 & 11 \\
\hline IFIT1 & $\begin{array}{l}\text { interferon induced protein with } \\
\text { tetratricopeptide repeats } 1\end{array}$ & 11 \\
\hline IFIT2 & $\begin{array}{l}\text { interferon induced protein with } \\
\text { tetratricopeptide repeats } 2\end{array}$ & 11 \\
\hline IFIT3 & $\begin{array}{l}\text { interferon induced protein with } \\
\text { tetratricopeptide repeats } 3\end{array}$ & 11 \\
\hline ISG15 & ISG15 ubiquitin like modifier & 11 \\
\hline MX1 & MX dynamin like GTPase 1 & 11 \\
\hline $\mathrm{MX} 2$ & MX dynamin like GTPase 2 & 11 \\
\hline OAS3 & 2 '-5'-oligoadenylate synthetase 3 & 11 \\
\hline XAF1 & XIAP associated factor 1 & 11 \\
\hline BST2 & bone marrow stromal cell antigen 2 & 10 \\
\hline CXCL10 & C-X-C motif chemokine ligand 10 & 10 \\
\hline DHX58 & DExH-box helicase 58 & 10 \\
\hline $\mathrm{IFIH1}$ & interferon induced with helicase C domain 1 & 10 \\
\hline IL6 & interleukin 6 & 10 \\
\hline IRF7 & interferon regulatory factor 7 & 10 \\
\hline OAS2 & $2^{\prime}-5^{\prime}$-oligoadenylate synthetase 2 & 10 \\
\hline PARP14 & $\begin{array}{l}\text { poly(ADP-ribose) polymerase family member } \\
14\end{array}$ & 10 \\
\hline RSAD2 & $\begin{array}{l}\text { radical S-adenosyl methionine domain } \\
\text { containing } 2\end{array}$ & 10 \\
\hline SP100 & SP100 nuclear antigen & 10 \\
\hline STAT1 & $\begin{array}{l}\text { signal transducer and activator of } \\
\text { transcription } 1\end{array}$ & 10 \\
\hline USP18 & ubiquitin specific peptidase 18 & 10 \\
\hline BATF2 & $\begin{array}{l}\text { basic leucine zipper ATF-like transcription } \\
\text { factor } 2\end{array}$ & 9 \\
\hline CXCL11 & C-X-C motif chemokine ligand 11 & 9 \\
\hline EPSTI1 & epithelial stromal interaction 1 & 9 \\
\hline HERC6 & $\begin{array}{l}\text { HECT and RLD domain containing E3 } \\
\text { ubiquitin protein ligase family member } 6\end{array}$ & 9 \\
\hline IFI35 & interferon induced protein 35 & 9 \\
\hline IFITM3 & interferon induced transmembrane protein 3 & 9 \\
\hline ISG20 & interferon stimulated exonuclease gene 20 & 9 \\
\hline PARP9 & $\begin{array}{l}\text { poly(ADP-ribose) polymerase family member } \\
9\end{array}$ & 9 \\
\hline PLAC8 & placenta associated 8 & 9 \\
\hline RTP4 & receptor transporter protein 4 & 9 \\
\hline SAMD9L & sterile alpha motif domain containing 9 like & 9 \\
\hline SP110 & SP110 nuclear body protein & 9 \\
\hline TRAFD1 & TRAF-type zinc finger domain containing 1 & 9 \\
\hline TRIM21 & tripartite motif containing 21 & 9 \\
\hline ZBP1 & Z-DNA binding protein 1 & 9 \\
\hline ZC3HAV1 & zinc finger $\mathrm{CCCH}$-type containing, antiviral 1 & 9 \\
\hline
\end{tabular}




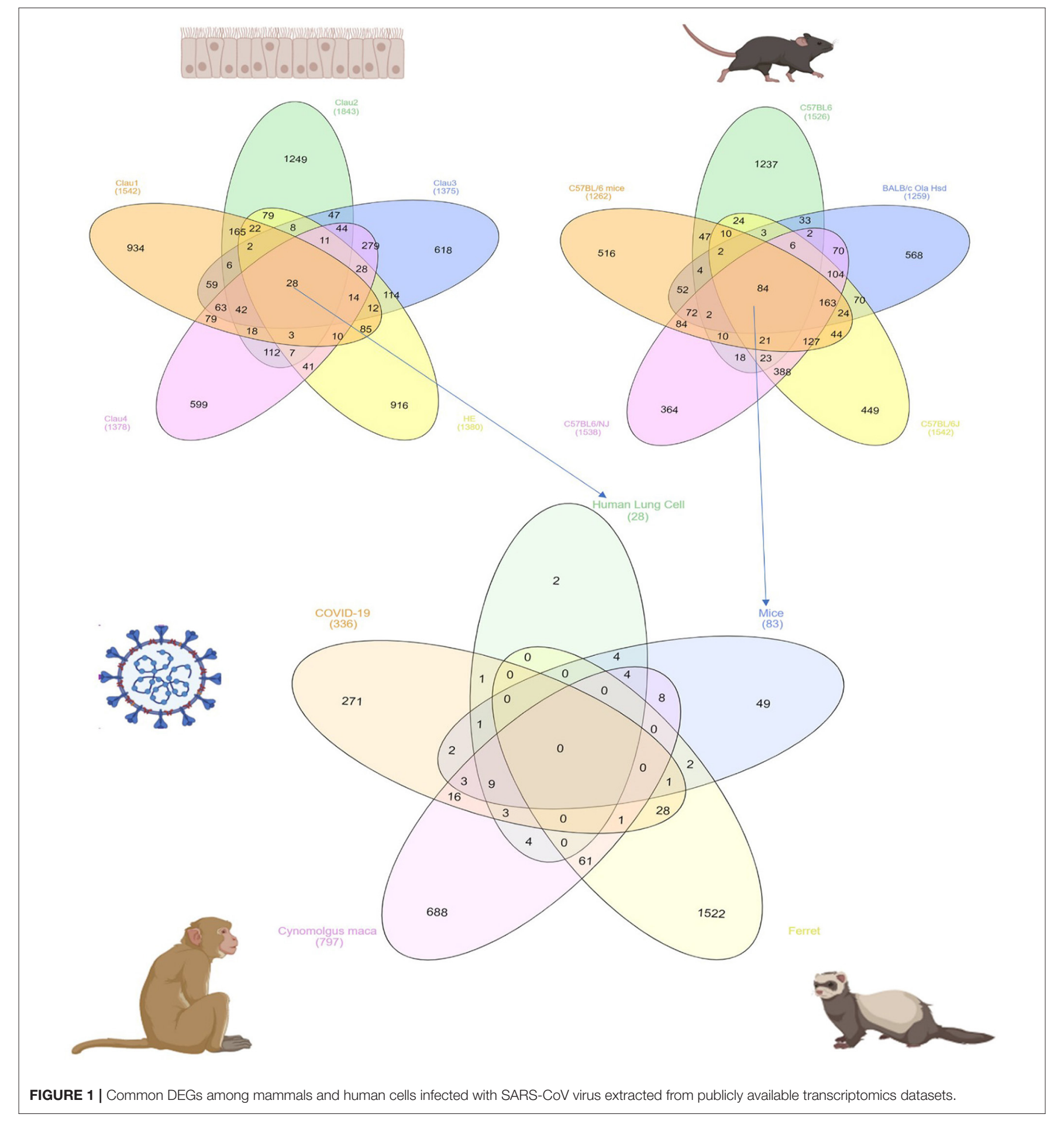

and were further induced by the virus, which results in overall high mRNA levels.

\section{Valproic Acid Can Upregulate the IFITM3 mRNA Expression}

Next, we searched the Comparative Toxicogenomics Database (http://ctdbase.org/) to identify drugs/chemicals that might affect the mRNA expression of IFITM3 in at least two reference studies (14). Interestingly valproic acid, carbon nanotubes, nickel, and tert-butylhydroperoxide were shown to upregulate IFITM3 expression while pirinixic acid, acetaminophen, and Ethinyl estradiol decreased such an expression (Table 5).

In order to examine the effect of valproic acid therapy on the IFITM3 mRNA expression in immune cells of the 
blood, a publicly available transcriptomics dataset (GSE143272) was extracted and reanalyzed. Healthy controls were compared to responders and non-responders patients on valproic acid therapy. We found upregulation of the mRNA expression of IFITM3 in patients, and the difference was significant in the responder group only $(p<0.05)$ compared to healthy controls (Figure 4).

TABLE 3 | Number of shared DEGs in different models infected with SARS-CoV extracted from publicly available transcriptomics datasets.

\begin{tabular}{|c|c|}
\hline Model infected & $\begin{array}{l}\text { Number } \\
\text { of DEGs }\end{array}$ \\
\hline [COVID-19] & 271 \\
\hline [COVID-19] and [Cynomolgus maca] & 16 \\
\hline [COVID-19] and [Ferret] & 28 \\
\hline [COVID-19] and [Ferret] and [Cynomolgus maca] & 1 \\
\hline [COVID-19] and [Human lung cell] & 1 \\
\hline [COVID-19] and [Human lung cell] and [Cynomolgus maca] & 3 \\
\hline [COVID-19] and [Human lung cell] and [Mice] & 1 \\
\hline [COVID-19] and [Human lung cell] and [Mice] and [Cynomolgus maca] & 9 \\
\hline [COVID-19] and [Mice] & 2 \\
\hline [COVID-19] and [Mice] and [Cynomolgus maca] & 3 \\
\hline [COVID-19] and [Mice] and [Ferret] & 1 \\
\hline [Cynomolgus maca] & 688 \\
\hline [Ferret] & 1,522 \\
\hline [Ferret] and [Cynomolgus maca] & 61 \\
\hline [Human lung cell] & 2 \\
\hline [Human lung cell] and [Cynomolgus maca] & 4 \\
\hline [Human lung cell] and [Mice] & 4 \\
\hline [Human lung cell] and [Mice] and [Cynomolgus maca] & 4 \\
\hline [Mice] & 49 \\
\hline [Mice] and [Cynomolgus maca] & 8 \\
\hline [Mice] and [Ferret] & 2 \\
\hline
\end{tabular}

\section{DISCUSSION}

In response to viral RNAs, like in the case of SARS-CoV-2, the innate immune system will unleash interferon (IFN), to activate antiviral mechanisms and effector cells like natural killers (15). In mice infected with SARS-CoV, a delayed and prolonged type I interferon (IFN-I) signaling leads to lung immunopathology as it promotes the accumulation of pathogenic inflammatory cells with increased lung cytokine/chemokine levels and vascular leakage (16). This prolonged IFN-I and virally induced IL-10 set the scene for secondary bacterial infection, which can add a strong IL1 $\beta$ and $\mathrm{TNF} \alpha$-mediated inflammatory response to magnify lung damage (17). Understanding how SARS-CoV-2 can manipulate IFN is vital in deciphering the battle of the body against the viral spread and consequence.

Our reanalysis of transcriptomic data showed that although the IFN pathway is upregulated consistently in SARS-CoV related infection, SARS-CoV-2 showed specific upregulation of the gene for a unique interferon-induced protein, namely IFITM3. IFITM3 is a $15-\mathrm{kDa}$ protein that localizes to endosomes and lysosomes and is possibly acquired by mammalian ancestral cells via horizontal gene transfer (18).

Interferon-induced transmembrane proteins (IFITMs 1, 2, and 3) are innate immune responders to virus infections as they regulate the fusion of invading virus and endocytic vesicles and direct it to the lysosomes (19, 20). IFITM3 can further alter membrane rigidity and curvature to inhibit virus membrane fusion (21). Such action is important to prevent the release of viral particles into the cytoplasm, which controls viral spread (22). During influenza A infection of human airway epithelial cells, IFITM3 was shown to clusters on viruscontaining endosomes and lysosomes within few hours postinfection, indicating its role in the early phase of viral entry (23). Even platelets and megakaryocytes were shown to remarkably upregulate IFITM3 to prevent viral progression during influenza infection (24).

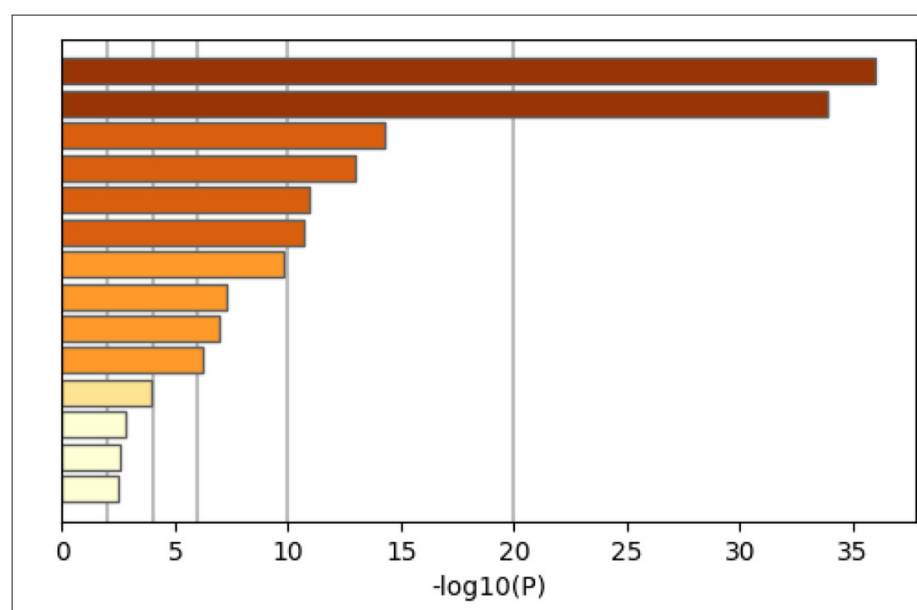

GO:0060337: type I interferon signaling pathway GO:0051607: defense response to virus R-HSA-1169410: Antiviral mechanism by IFN-stimulated genes hsa05164: Influenza A

GO:0060759: regulation of response to cytokine stimulus GO:0032479: regulation of type I interferon production GO:0035455: response to interferon-alpha hsa04623: Cytosolic DNA-sensing pathway GO:0050688: regulation of defense response to virus hsa04620: Toll-like receptor signaling pathway GO:0050777: negative regulation of immune response GO:0002262: myeloid cell homeostasis GO:0051100: negative regulation of binding GO:0043902: positive regulation of multi-organism process

FIGURE 2 | Enriched Ontology Clustering for the 38 identified DEGs. 
TABLE 4 | Enriched Ontology Clustering for the 38 DEGs identified with Genes symbols in each category.

\begin{tabular}{|c|c|c|c|c|c|c|}
\hline Category & Term & Description & $\log P$ & Log (q-value) & InTerm_InList & Symbols \\
\hline $\begin{array}{l}\text { GO biological } \\
\text { processes }\end{array}$ & GO:0060337 & $\begin{array}{l}\text { Type I interferon } \\
\text { signaling pathway }\end{array}$ & -36.0121 & -31.994 & $19 / 95$ & $\begin{array}{l}\text { BST2, IFI35, IFIT2, IFIT1, IFIT3, IRF7, ISG20, } \\
\text { MX1, MX2, OAS2, OAS3, SP100, STAT1, } \\
\text { ISG15, IFITM3, USP18, XAF1, ZBP1, RSAD2, } \\
\text { TRIM21, DDX58, IL6, CXCL10, CXCL11, } \\
\text { PARP14, PARP9, ZC3HAV1, DHX58 }\end{array}$ \\
\hline $\begin{array}{l}\text { GO biological } \\
\text { processes }\end{array}$ & GO:0051607 & $\begin{array}{l}\text { Defense response to } \\
\text { virus }\end{array}$ & -33.8766 & -30.160 & $22 / 248$ & $\begin{array}{l}\text { BST2, IFIT2, IFIT1, IFIT3, IL6, CXCL10, IRF7, } \\
\text { ISG20, MX1, MX2, OAS2, OAS3, STAT1, } \\
\text { ISG15, IFITM3, DDX58, ZC3HAV1, RTP4, } \\
\text { IFIH1, DHX58, PARP9, RSAD2, IFI44, PLAC8, } \\
\text { BATF2 }\end{array}$ \\
\hline Reactome gene sets & R-HSA-1169410 & $\begin{array}{l}\text { Antiviral mechanism by } \\
\text { IFN-stimulated genes }\end{array}$ & -14.292 & -11.274 & $9 / 81$ & $\begin{array}{l}\text { IFIT1, MX1, MX2, OAS2, OAS3, STAT1, ISG15, } \\
\text { USP18, DDX58 }\end{array}$ \\
\hline KEGG pathway & hsa05164 & Influenza A & -12.9643 & -9.967 & $10 / 173$ & $\begin{array}{l}\text { IL6, CXCL10, IRF7, MX1, OAS2, OAS3, STAT1, } \\
\text { DDX58, IFIH1, RSAD2, BST2, SP100, TRIM21, } \\
\text { IFITM3, PARP14, PARP9, IFIT1 }\end{array}$ \\
\hline $\begin{array}{l}\text { GO biological } \\
\text { processes }\end{array}$ & GO:0060759 & $\begin{array}{l}\text { Regulation of response } \\
\text { to cytokine stimulus }\end{array}$ & -10.9357 & -8.032 & $9 / 188$ & $\begin{array}{l}\text { IL6, IRF7, STAT1, USP18, DDX58, PARP14, } \\
\text { IFIH1, ZBP1, PARP9, ZC3HAV1 }\end{array}$ \\
\hline $\begin{array}{l}\text { GO biological } \\
\text { processes }\end{array}$ & GO:0032479 & $\begin{array}{l}\text { Regulation of type I } \\
\text { interferon production }\end{array}$ & -10.6988 & -7.826 & $8 / 127$ & $\begin{array}{l}\text { IRF7, TRIM21, STAT1, ISG15, DDX58, IFIH1, } \\
\text { DHX58, ZBP1, TRAFD1, USP18, PARP14, } \\
\text { PARP9, RSAD2, CXCL10, BST2, IL6, IFIT1, } \\
\text { SP100, BATF2 }\end{array}$ \\
\hline $\begin{array}{l}\text { GO biological } \\
\text { processes }\end{array}$ & GO:0035455 & $\begin{array}{l}\text { Response to } \\
\text { interferon-alpha }\end{array}$ & -9.83448 & -7.021 & $5 / 21$ & BST2, IFIT2, IFIT3, MX2, IFITM3, STAT1, XAF1 \\
\hline KEGG pathway & hsa04623 & $\begin{array}{l}\text { Cytosolic DNA-sensing } \\
\text { pathway }\end{array}$ & -7.31693 & -.600 & $5 / 63$ & $\begin{array}{l}\text { IL6, CXCL10, IRF7, DDX58, ZBP1, USP18, } \\
\text { TRIM21 }\end{array}$ \\
\hline $\begin{array}{l}\text { GO biological } \\
\text { processes }\end{array}$ & GO:0050688 & $\begin{array}{l}\text { Regulation of defense } \\
\text { response to virus }\end{array}$ & -6.93272 & -4.247 & $5 / 75$ & $\begin{array}{l}\text { IFIT1, STAT1, DDX58, DHX58, PARP9, BST2, } \\
\text { IL6, RSAD2 }\end{array}$ \\
\hline KEGG pathway & hsa04620 & $\begin{array}{l}\text { Toll-like receptor } \\
\text { signaling pathway }\end{array}$ & -6.22049 & -3.626 & $5 / 104$ & $\begin{array}{l}\text { IL6, CXCL10, IRF7, CXCL11, STAT1, OAS2, } \\
\text { ISG15, IFI44, PLAC8, HERC6, DHX58, SP100 }\end{array}$ \\
\hline $\begin{array}{l}\text { GO biological } \\
\text { processes }\end{array}$ & GO:0050777 & $\begin{array}{l}\text { negative regulation of } \\
\text { immune response }\end{array}$ & -3.98249 & -1.608 & $4 / 156$ & BST2, TRAFD1, PARP14, DHX58 \\
\hline $\begin{array}{l}\text { GO biological } \\
\text { processes }\end{array}$ & GO:0002262 & $\begin{array}{l}\text { Myeloid cell } \\
\text { homeostasis }\end{array}$ & -2.78923 & -0.508 & $3 / 148$ & IL6, STAT1, ISG15, IRF7, BATF2 \\
\hline $\begin{array}{l}\text { GO biological } \\
\text { processes }\end{array}$ & GO:0051100 & $\begin{array}{l}\text { Negative regulation of } \\
\text { binding }\end{array}$ & -2.61062 & -0.352 & $3 / 171$ & IFIT2, IFIT1, SP100, PARP9 \\
\hline $\begin{array}{l}\text { GO biological } \\
\text { processes }\end{array}$ & GO:0043902 & $\begin{array}{l}\text { Positive regulation of } \\
\text { multi-organism process }\end{array}$ & -2.50748 & -0.264 & $3 / 186$ & IFIT1, TRIM21, DHX58, IFITM3 \\
\hline
\end{tabular}

The epithelial cell and resident leukocytes in lung upper and lower airways that constitutively express IFITM 3 can withstand viral infections, and this is vital to decide viral tropism as viruses favor cells with low IFITM3 expression (25). IFITM3 enhances the accumulation of CD8 $+\mathrm{T}$ cells in airways to promote mucosal immune cell persistence (26). Lung and circulating immune cells were reported to express less IFITM3 than other tissues, and this was a suggestive reason for COVID-19 severity and cytokine release syndrome (27).

Interestingly, IFITM3-rs12252-C/C SNP prevalence in the Chinese population is $26.5 \%$, and recent research confirmed that SNPs in IFITM3 could change the severity of influenza infection, as was shown in one case with COVID-19 (28). IFITM3 polymorphisms have been linked with hospitalization and mortality during influenza virus infection (29).

Expressing the gene is not the only prerequisite to the antiviral action of IFITM3, as it was found recently that within the protein, an amphipathic helix is critical for its blocking effect of viral fusion of similar pathogenic viruses like influenza A virus and Zika virus (30). Another factor that regulates the IFITM3 trafficking specificity to such viruses is that it requires S-palmitoylation $(19,20)$. S-palmitoylation (SPALM) is the reversible process of linking a fatty acid chain to cysteine residues of the substrate protein (31). Multiple zinc finger DHHC domain-containing palmitoyltransferases (ZDHHCs) can palmitoylate IFITM3 to make it a fully functional antiviral protein (32). It seems that bats (order Chiroptera), which act as natural hosts for many viral infections, use IFITM3 as an antiviral mechanism if there is S-palmitoylation of the protein; however, if this modification is disturbed, the bat can develop viral infection (33). Based on that, we can suggest that severe COVID-19 cases might be due to either non-functional IFITM3 by SNP, failure of lung cells to upregulate IFITM3 in response to interferon, a mutation in amphipathic helix sequence or modification in S-palmitoylation. Further examination and screening for the IFITM3 dynamics 


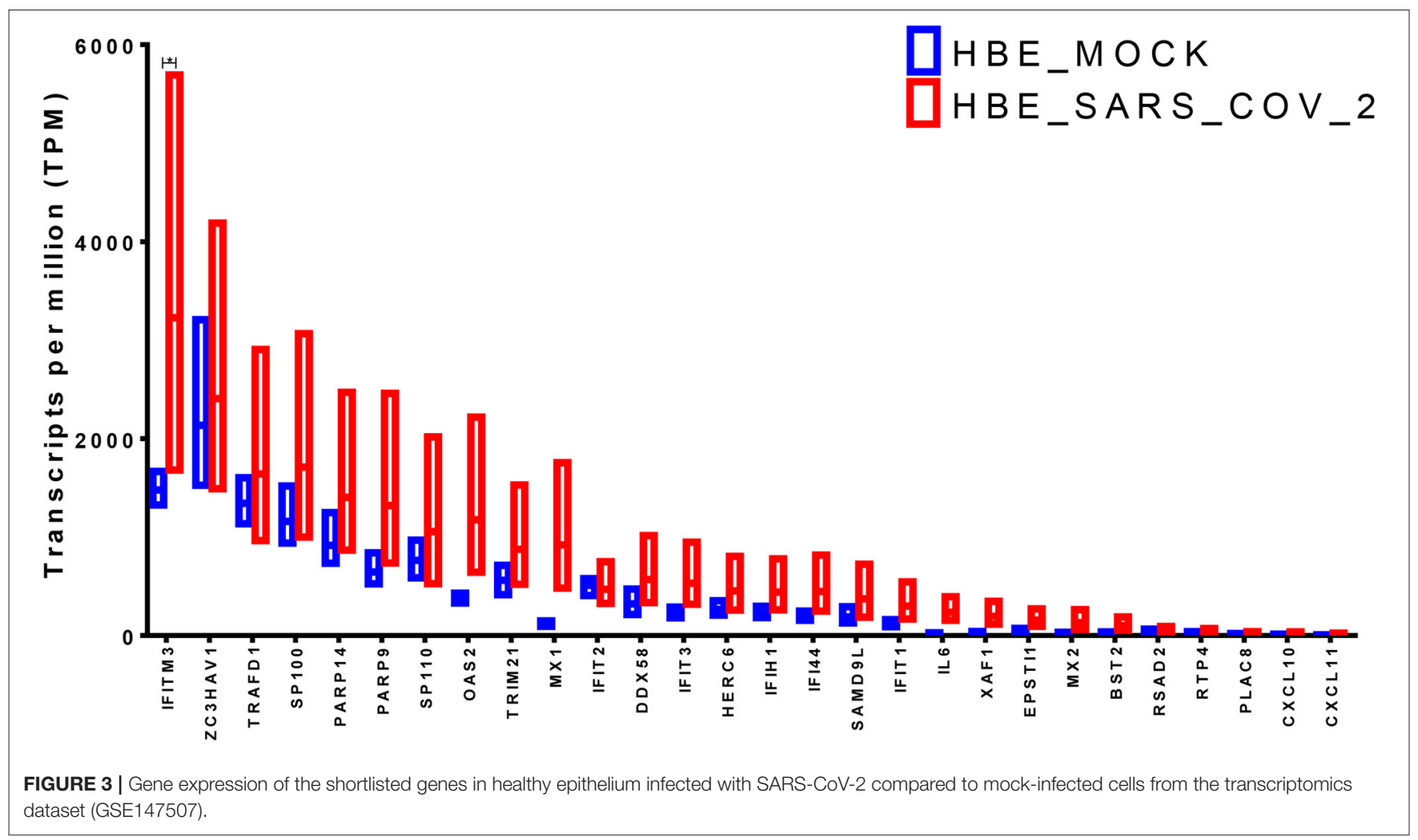

TABLE 5 | Chemicals shown to upregulate or downregulate IFITM3 mRNA expression in at least two studies as shown in the Comparative Toxicogenomics Database (http://ctdbase.org/).

\begin{tabular}{|c|c|c|c|c|c|c|}
\hline Chemical name & Chemical ID & CAS RN & Interaction & $\begin{array}{l}\text { Effect on IFITM3 } \\
\text { mRNA expression }\end{array}$ & $\begin{array}{l}\text { Reference } \\
\text { count }\end{array}$ & $\begin{array}{c}\text { Organism } \\
\text { count }\end{array}$ \\
\hline Valproic acid & D014635 & $99-66-1$ & $\begin{array}{l}\text { Valproic acid results in increased expression of } \\
\text { IFITM3 mRNA }\end{array}$ & increases & 3 & 2 \\
\hline Nanotubes, carbon & D037742 & & $\begin{array}{l}\text { Nanotubes, carbon analog results in increased } \\
\text { expression of IFITM3 mRNA }\end{array}$ & increases & 2 & 1 \\
\hline Nickel & D009532 & $7440-02-0$ & $\begin{array}{l}\text { Nickel results in increased expression of IFITM3 } \\
\text { mRNA }\end{array}$ & increases & 2 & 1 \\
\hline Pirinixic acid & C006253 & $50892-23-4$ & $\begin{array}{l}\text { Pirinixic acid results in decreased expression of } \\
\text { IFITM3 mRNA }\end{array}$ & decreases & 3 & 2 \\
\hline Acetaminophen & D000082 & $103-90-2$ & $\begin{array}{l}\text { Acetaminophen results in decreased } \\
\text { expression of IFITM3 mRNA }\end{array}$ & decreases & 2 & 1 \\
\hline
\end{tabular}

in COVID-19 might explain the possible therapeutic and diagnostic options.

Our toxicogenomic analysis showed that valproic acid increased the mRNA expression of IFITM3, supporting a new report that the SARS-CoV-2-human protein-protein interaction map showed that valproic acid might be a potential repurposing drug for COVID-19 (34). Virtual screening, docking, binding energy calculation, and simulation show that valproic acid forms stable interaction with nsP12 of $\mathrm{CoV}$ and can inhibit its function
(14). Valproic acid is currently used for the treatment of epilepsy and known to target histone deacetylases (HDACs) that modify the gene expression epigenetically (35). Valproic acid was shown to inhibit mature and fully infectious enveloped viruses release as it alters cellular membrane composition (36). The modest and broad antiviral activity of valproic acid made the drug an attractive possibility due to its availability, and limited side effects for a short term of use during acute viral disease (37). The reported side effects like hepatotoxicity and teratogenicity are 


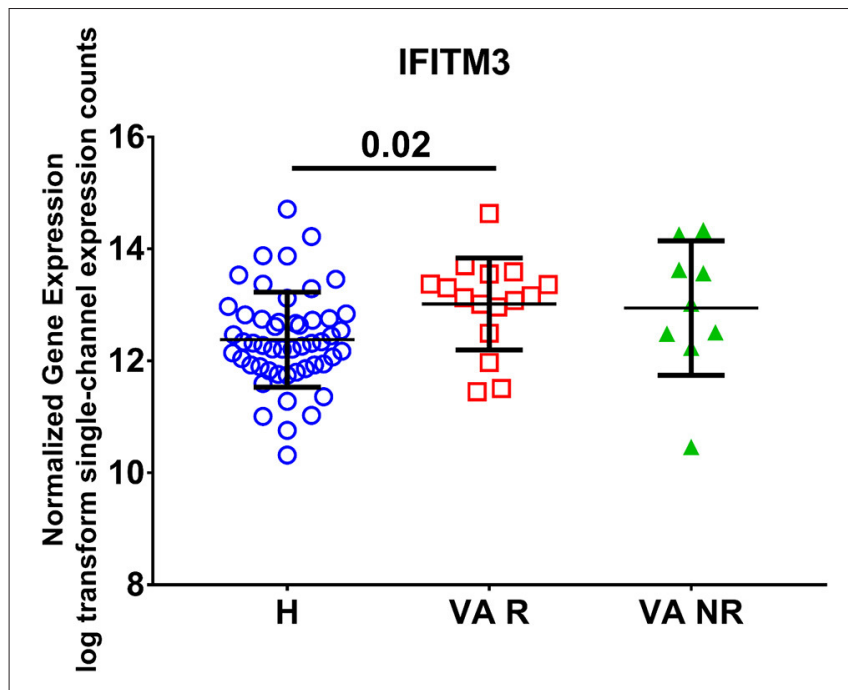

FIGURE 4 | Normalized gene expression of IFITM3 in the blood of patients on responder valproic acid monotherapy (VA R) and non-response (VA NR) compared to healthy controls $(\mathrm{H})$ extracted from the transcriptomic dataset (GSE143272).

mainly associated with the parental compound valproate and can be avoided by the use of its derivatives like Valpromide (VPD) and valnoctamide (VCD). A recent open-label proof-of-concept trial of 10 days Intravenous Valproic Acid for Severe COVID-19 showed a $50 \%$ reduction in the case fatality rate and length of stay

\section{REFERENCES}

1. Ng LFP, Hiscox JA. Coronaviruses in animals and humans. BMJ. (2020) 368:m634. doi: 10.1136/bmj.m634

2. Guarner J. Three emerging coronaviruses in two decades. Am J Clini Pathol. (2020) 153:420-1. doi: 10.1093/ajcp/aqaa029

3. Fauci AS, Lane HC, Redfield RR. Covid-19 - navigating the uncharted. N Engl J Med. (2020) 382:1268-9. doi: 10.1056/NEJMe2002387

4. Cameron MJ, Kelvin AA, Leon AJ, Cameron CM, Ran L, Xu L, et al. Lack of innate interferon responses during SARS coronavirus infection in a vaccination and reinfection ferret model. PLoS ONE. (2012) 7:e45842. doi: 10.1371/journal.pone.0045842

5. Yoshikawa T, Hill TE, Yoshikawa N, Popov VL, Galindo CL, Garner HR, et al. Dynamic innate immune responses of human bronchial epithelial cells to severe acute respiratory syndrome-associated coronavirus infection. PLoS ONE. (2010) 5:e8729. doi: 10.1371/journal.pone.0008729

6. Rockx B, Feldmann F, Brining D, Gardner D, LaCasse R, Kercher $\mathrm{L}$, et al. Comparative pathogenesis of three human and zoonotic SARS-CoV strains in cynomolgus macaques. PLoS ONE. (2011) 6:e18558. doi: 10.1371/journal.pone.0018558

7. Gralinski LE, Sheahan TP, Morrison TE, Menachery VD, Jensen K, Leist SR, et al. Complement activation contributes to severe acute respiratory syndrome coronavirus pathogenesis. mBio. (2018) 9:e0175318. doi: $10.1128 / \mathrm{mBio} .01753-18$

8. Sims AC, Tilton SC, Menachery VD, Gralinski LE, Schäfer A, Matzke MM, et al. Release of severe acute respiratory syndrome coronavirus nuclear import block enhances host transcription in human lung cells. J Virol. (2013) 87:3885902. doi: 10.1128/jvi.02520-12

9. Mitchell HD, Eisfeld AJ, Sims AC, McDermott JE, Matzke MM, WebbRobertson BJ, et al. A network integration approach to predict conserved
(38). More studies are needed to explore the promising potential of valproic acid in the treatment of COVID-19.

One limitation of the study is that it is based on the publicly available transcriptome dataset, which is limited in number, partly because this is a novel disease, but also because ongoing lockdowns have made it challenging for scientists to carry out the extensive laboratory work required.

\section{CONCLUSION}

Our evaluation showed that the analysis of publicly available transcriptomic data could be a reasonable approach to identify the novel target and suggest drugs that can modify the action of such targets during the early phases of emerging infections like COVID-19 until a complete understanding of the disease become clear. This can justify the experimental use of clinically approved drugs and guide the clinicians in their limited options against such lethal disease.

\section{DATA AVAILABILITY STATEMENT}

All datasets presented in this study are included in the article/supplementary material.

\section{AUTHOR CONTRIBUTIONS}

All authors listed have made a substantial, direct and intellectual contribution to the work, and approved it for publication. regulators related to pathogenicity of influenza and SARS-CoV respiratory viruses. PLoS ONE. (2013) 8:e69374. doi: 10.1371/journal.pone.0069374

10. Jimenez-Guardeño JM, Nieto-Torres JL, DeDiego ML, Regla-Nava JA, Fernandez-Delgado R, Castaño-Rodriguez $\mathrm{C}$, et al. The PDZ-binding motif of severe acute respiratory syndrome coronavirus envelope protein is a determinant of viral pathogenesis. PLoS Pathog. (2014) 10:e1004320. doi: 10.1371/journal.ppat.1004320

11. Totura AL, Whitmore A, Agnihothram S, Schäfer A, Katze MG, Heise MT, et al. Toll-like receptor 3 signaling via TRIF contributes to a protective innate immune response to severe acute respiratory syndrome coronavirus infection. mBio. (2015) 6:e00638-15. doi: 10.1128/mBio.00638-15

12. Barrett T, Wilhite SE, Ledoux P, Evangelista C, Kim IF, Tomashevsky M, et al. NCBI GEO: archive for functional genomics data sets-update. Nucleic Acids Res. (2012) 41:D991-5. doi: 10.1093/nar/gks1193

13. Blanco-Melo D, Nilsson-Payant BE, Liu W-C, Møller R, Panis M, Sachs $\mathrm{D}$, et al. SARS-CoV-2 launches a unique transcriptional signature from in vitro, ex vivo, and in vivo systems. bioRxiv. [Preprint]. (2020). doi: $10.1101 / 2020.03 .24 .004655$

14. Davis AP, Grondin CJ, Johnson RJ, Sciaky D, McMorran R, Wiegers J, et al. The comparative toxicogenomics database: update 2019. Nucleic Acids Res. (2019) 47:D948-54. doi: 10.1093/nar/gky868

15. Nelemans T, Kikkert $M$. Viral innate immune evasion and the pathogenesis of emerging RNA virus infections. Viruses. (2019) 11:961. doi: 10.3390/v11100961

16. Channappanavar R, Fehr AR, Vijay R, Mack M, Zhao J, Meyerholz DK, et al. Dysregulated type I interferon and inflammatory monocyte-macrophage responses cause lethal pneumonia in SARS-CoV-infected mice. Cell Host Microbe. (2016) 19:181-93. doi: 10.1016/j.chom.2016.01.007

17. Boucontet L, Passoni G, Thiry V, Maggi L, Herbomel P, Levraud J-P et al. A model of superinfection of virus-infected zebrafish larvae: increased 
susceptibility to bacteria associated with neutrophil death. Front Immunol. (2018) 9:1084. doi: 10.3389/fimmu.2018.01084

18. Shi G, Schwartz O, Compton AA. More than meets the I: the diverse antiviral and cellular functions of interferon-induced transmembrane proteins. Retrovirology. (2017) 14:53. doi: 10.1186/s12977-017-0377-y

19. Spence JS, He R, Hoffmann H-H, Das T, Thinon E, Rice CM, et al. IFITM3 directly engages and shuttles incoming virus particles to lysosomes. Nat Chem Biol. (2019) 15:259-68. doi: 10.1038/s41589-018-0213-2

20. Suddala KC, Lee CC, Meraner P, Marin M, Markosyan RM, Desai $\mathrm{TM}$, et al. Interferon-induced transmembrane protein 3 blocks fusion of sensitive but not resistant viruses by partitioning into virus-carrying endosomes. PLoS Pathog. (2019) 15:e1007532. doi: 10.1371/journal.ppat. 1007532

21. Li K, Markosyan RM, Zheng YM, Golfetto O, Bungart B, Li M, et al. IFITM proteins restrict viral membrane hemifusion. PLoS Pathog. (2013) 9:e1003124. doi: 10.1371/journal.ppat.1003124

22. Zani A, Yount JS. Antiviral protection by IFITM3 in vivo. Curr Clin Microbiol Rep. (2018) 5:229-37. doi: 10.1007/s40588-018-0103-0

23. Kummer S, Avinoam O, Kräusslich HG. IFITM3 clusters on virus containing endosomes and lysosomes early in the influenza A infection of human airway epithelial cells. Viruses. (2019) 11:548. doi: 10.3390/v11 060548

24. Campbell RA, Schwertz H, Hottz ED, Rowley JW, Manne BK, Washington AV, et al. Human megakaryocytes possess intrinsic antiviral immunity through regulated induction of IFITM3. Blood. (2019) 133:2013-26. doi: 10.1182/blood-2018-09-873984

25. Wellington D, Laurenson-Schafer H, Abdel-Haq A, Dong T. IFITM3: How genetics influence influenza infection demographically. Biomed J. (2019) 42:19-26. doi: 10.1016/j.bj.2019.01.004

26. Wakim LM, Gupta N, Mintern JD, Villadangos JA. Enhanced survival of lung tissue-resident memory CD8(+) T cells during infection with influenza virus due to selective expression of IFITM3. Nat Immunol. (2013) 14:23845. doi: 10.1038/ni.2525

27. Dai Y-J, Zhang W-N, Wang W-D, He S-Y, Liang C-C, Wang D-W. Two potential novel SARS-CoV-2 entries, TMPRSS2 and IFITM3, in healthy individuals and cancer patients. Healthy Individuals Cancer Patients (2020).

28. Everitt AR, Clare S, Pertel T, John SP, Wash RS, Smith SE, et al. IFITM3 restricts the morbidity and mortality associated with influenza. Nature. (2012) 484:519-23. doi: 10.1038/nature10921

29. Allen EK, Randolph AG, Bhangale T, Dogra P, Ohlson M, Oshansky CM, et al. SNP-mediated disruption of CTCF binding at the IFITM3 promoter is associated with risk of severe influenza in humans. Nat Med. (2017) 23:975-83. doi: $10.1038 / \mathrm{nm} .4370$
30. Chesarino NM, Compton AA, McMichael TM, Kenney AD, Zhang L, Soewarna V, et al. IFITM3 requires an amphipathic helix for antiviral activity. EMBO Rep. (2017) 18:1740-51. doi: 10.15252/embr.201744100

31. Zareba-Kozioł M, Figiel I, Bartkowiak-Kaczmarek A, Włodarczyk J. Insights into protein S-palmitoylation in synaptic plasticity and neurological disorders: potential and limitations of methods for detection and analysis. Front $\mathrm{Mol}$ Neurosci. (2018) 11:175. doi: 10.3389/fnmol.2018.00175

32. McMichael TM, Zhang L, Chemudupati M, Hach JC, Kenney AD, Hang HC, et al. The palmitoyltransferase ZDHHC20 enhances interferoninduced transmembrane protein 3 (IFITM3) palmitoylation and antiviral activity. J Biol Chem. (2017) 292:21517-26. doi: 10.1074/jbc.M117.8 00482

33. Benfield CT, MacKenzie F, Ritzefeld M, Mazzon M, Weston S, Tate $\mathrm{E}$, et al. Bat IFITM3 restriction depends on S-palmitoylation and a polymorphic site within the CD225 domain. Life Sci Alliance. (2020) 3:e201900542. doi: 10.26508/lsa.201900542

34. Gordon DE, Jang GM, Bouhaddou M, Xu J, Obernier K, O’Meara $\mathrm{MJ}$, et al. A SARS-CoV-2-human protein-protein interaction map reveals drug targets and potential drug-repurposing. bioRxiv. (2020). doi: 10.1101/2020.03.22.002386

35. Sixto-López Y, Bello M, Correa-Basurto J. Exploring the inhibitory activity of valproic acid against the HDAC family using an MMGBSA approach. J Comput Aided Mol Des. (2020). doi: 10.1007/s10822-02000304-2. [Epub ahead of print].

36. Wisskirchen K, Lucifora J, Michler T, Protzer U. New pharmacological strategies to fight enveloped viruses. Trends Pharmacol Sci. (2014) 35:4708. doi: 10.1016/j.tips.2014.06.004

37. Domingo E. Trends in antiviral strategies. In: Virus as Populations (Second Edition). editor E. Domingo. London: Academic Press (2020).

38. Chiquete E, Toapanta-Yanchapaxi L, Cantu-Brito C. Methods of an openlabel proof-of-concept trial of intravenous valproic acid for severe COVID-19. medRxiv. [Preprint]. (2020). doi: 10.1101/2020.04.26.20079988

Conflict of Interest: The authors declare that the research was conducted in the absence of any commercial or financial relationships that could be construed as a potential conflict of interest.

Copyright (c) 2020 Hachim, Al Heialy, Hachim, Halwani, Senok, Maghazachi and Hamid. This is an open-access article distributed under the terms of the Creative Commons Attribution License (CC BY). The use, distribution or reproduction in other forums is permitted, provided the original author(s) and the copyright owner(s) are credited and that the original publication in this journal is cited, in accordance with accepted academic practice. No use, distribution or reproduction is permitted which does not comply with these terms. 